\title{
Antibacterial Activity of Betel (Piper betle L.) Leaf Extracts towards
}

\section{Aggregatibacteractinomycetemcomitans and Porphyromonasgingivalis}

\author{
Nunung Rusminah ${ }^{1}$, Agus Susanto ${ }^{2}$ \\ Department of Periodontics Faculty of Dentistry Universitas Padjadjaran, Indonesia
}

\begin{abstract}
Aggregatibacteractinomycetemcomitans (Aa) and Porphyromonasgingivalis (Pg) are the dominant bacteria in periodontal disease. The purpose of this study was to determine the inhibitory potential of betel leaf extract gel towards Aa and Pg bacteria. Methods: This study was an in vitro experimental laboratory. The first stage of the study was the phytochemical eradication of the betel leaf extract. Determination of the minimum inhibitory concentration of the betel leaf extract gel was done by observing the lowest concentration seen clearly for the first time. The antibacterial activity test was performed by using agar diffusion method, to determine the betel leaf extract gel inhibitory zone towards Aa and Pg bacteria. Results: Based on the qualitative phytochemical analysis, betel leaf extract contained alkaloids, flavonoids, polyphenols, tannins, monoterpenoids, and sesquiterpenoids. The minimum inhibitory concentration of betel leaf extract gel towards Aa was as much as 12.5\%, whilst towards Pg was as much as 25\%. Inhibitory zone of betel leaf extract gel towards Aa and Pg bacteria was $14.70 \mathrm{~mm}$ and $8.95 \mathrm{~mm}$ consecutively. Conclusion: The betel leaf extract gel was having the ability to inhibit the growth of Aggregatibacteractinomycetemcomitans and Porphyromonasgingivalis.
\end{abstract}

Keyword: Antibacterial activity, Aggregatibacteractinomycetemcomitans (Aa), betel leaf extract, Porphyromonasgingivalis (Pg)

\section{Introduction}

Periodontal disease is one of the most common oral diseases which having the high prevalence in the society. Periodontal disease is an inflammatory disease affecting the tissues surrounding the teeth. There are two types periodontal diseases, which are gingivitis and periodontitis. Gingivitis is a non-destructive inflammatory disease affecting the gums, whereas periodontitis is a set of inflammatory disease affecting the periodontal tissues including gums, periodontal membranes, cementum and alveolar bone. Periodontitis involves the formation of periodontal pockets, clinical attachment loss, and alveolar bone destruction[1].

The etiology of periodontal disease is multifactorial, but the presence of bacteria becomes an important factor in the pathogenesis, therefore, bacterial presence is the main cause of periodontal disease[2],[3]. Dental plaque bacterial affecting the body's immune response and produce various metabolites such as ammonia $\left(\mathrm{NH}_{3}\right)$, hydrogen sulfide $\left(\mathrm{H}_{2} \mathrm{~S}\right)$, butyric acid, and propionic acid, that contributes directly to the tissue damage. Anaerobic gram-negative bacteria dominate the bacteria involvement in periodontitis disease. Porphyromonasgingivalis (Pg) and Aggregatibacteractonomycetemcomitans (Aa) are gramnegative bacteria that often associated with periodontitis. These bacteria are important pathogens and associated significantly with periodontal disease status, severity, and treatment failure[3],[4]. Periodontal pathogens such as Pg and Aa have reported of having the efficacy on invading the gum and connective tissues. This condition makes bacteria in the tissue as a reservoir for reinfection after non-surgical treatment (scaling and root planning). Reports of bacterial presence in the tissues had become a justification for the use of antibiotics in the treatment of periodontitis[4].
The use of antibiotics is needed to inhibit or control the bacterial infections because bacteria was able to invade the periodontal tissues that lessened the effectivity of nonsurgical mechanical treatments such as scaling and root planning on periodontal disease. The use of this antibacterial is an additional therapy of scaling and root planning. Local antibacterial administration of the periodontal pocket has a better potential as it is directly affecting the infection area, having higher concentration in the infection area, and reduces the possibility of the medication side effects[5],[6].

Betel plants have been widely used in various traditional herbal remedies, and proven as an effective treatment of various kinds of infectious diseases. This plant has been known to have antioxidant, anti-inflammatory and antibacterial activity. Herbal plants have advantages in remedies due to the minimal side effects compared to synthetical antibiotics. Previous studies of betel extract have shown the strong antibacterial activity towards $C$. albicans, $S$. aureus, and $M$. pachydermatis [7],[8]. Based on the description above, this study was aimed to determine the inhibitory potential of betel leaf extract gel towards Aa and $\mathrm{Pg}$ bacteria which is the dominant bacteria in periodontal disease.

\section{Materials and Methods}

The material tested is green betel leaf (Piper betle L.) simplisia originating from the area around the city of Bandung, West Java. Bacteria used were Aggregatibacteractinomycetemcomitans (Aa) and Porphyromonasgingivalis $(\mathrm{Pg})$. The media used for the antibacterial test was Mueller-Hinton agar (MHA). Antibiotics used as a positive control was tetracycline. 


\section{International Journal of Science and Research (IJSR) \\ ISSN (Online): 2319-7064}

Index Copernicus Value (2016): 79.57 | Impact Factor (2015): 6.391

Extraction of the betel leaf was performed by selecting old betel leaves, which were the fourth and the fifth leaf from the shoots. Then the heat extraction was used to extract the betel leaf. Dry betel leaf simplisia was extracted with water at the temperature of $96-98^{\circ} \mathrm{C}$ for 30 minutes then filtered. The filtrate was evaporated using a rotavapor at the temperature of $70^{\circ} \mathrm{C}$ to obtain a concentrated extract. The process continued by evaporating the concentrated extract on the water bath until obtained a dry extract.

The antibacterial activity was performed with a plate/paper disk diffusion method. The experimental organisms (Aa and $\mathrm{Pg}$ ) were grown in BHI (Brain Heart Infusion) and incubated for 24 hours. Then were diluted with McFarland standards no. 0.5 (containing $1.5108 \mathrm{CFU} / \mathrm{ml}$ ) of standardized bacteria, grown on Mueller-Hinton agar by swabbed with sterile cotton swabs. After that, the paper plate was dropped with $10 \mu \mathrm{l}$ of tetracycline, and betel leaf gel was placed on the agar medium then measured the inhibitory zone towards Aa and Pg bacteria.

\section{Results}

Based on the qualitative phytochemical analysis, betel leaf extract contained alkaloids, flavonoids, polyphenols, tannins, monoterpenoids, and sesquiterpenoids, as presented in Table 1.

Table 1: Betel leaf extractphytochemical screening results

\begin{tabular}{|c|c|}
\hline Compound category & Result \\
\hline Polyphenols & + \\
\hline Alkaloids & + \\
\hline Flavonoids & + \\
\hline Quinone & - \\
\hline Saponins & - \\
\hline Tannins & + \\
\hline MonoterpenoidsandSesquiterpenoids & + \\
\hline Steroid danTriterpenoids & - \\
\hline
\end{tabular}

Notes : (-) not detected

$(+)$ detected

Assessment of the minimum inhibitory concentration (MIC) test of betel leaf extract towards $\mathrm{Aa}$ and Pg bacteria based on the turbidity level found in the reaction tube containing the $\mathrm{NB}$ medium and Aa and Pg bacteria resulted that the MIC of the betel leaf extract gel towards the Aa bacteria was as much as $12.5 \%$, and the minimum killing concentration (MKC) was as much as $25 \%$, characterized by the absence of Aa bacteria growth in such concentration level. Whilst the MIC of the betel leaf extract gel towards the Pg bacteria was as much as $25 \%$, and the MKC was as much as $50 \%$, characterized by the absence of $\mathrm{Pg}$ bacteria growth in such concentration level.

The results of the antibacterial activity test with the agar diffusion method showed that there was an inhibitorial activity of the betel leaf extract gel towards the growth ofAadanPg bacteriaas shown in Table 2.
Table 2: Inhibitory zone diameter (in $\mathrm{mm}$ ) of the betel leaf extract gel and tetracycline towards $\mathrm{Aa}$ and $\mathrm{Pg}$ bacteria

\begin{tabular}{|c|c|c|}
\hline Sample (100\%) & $\begin{array}{c}\text { Inhibitory zone } \\
\text { diameter }(\mathrm{mm})\end{array}$ & Notes \\
\hline $\mathrm{Aa}$ & 14.70 & Susceptible \\
\hline $\mathrm{Pg}$ & 8.95 & Susceptible \\
\hline Tetrasiklin (positive control) & 46.40 & Susceptible \\
\hline
\end{tabular}

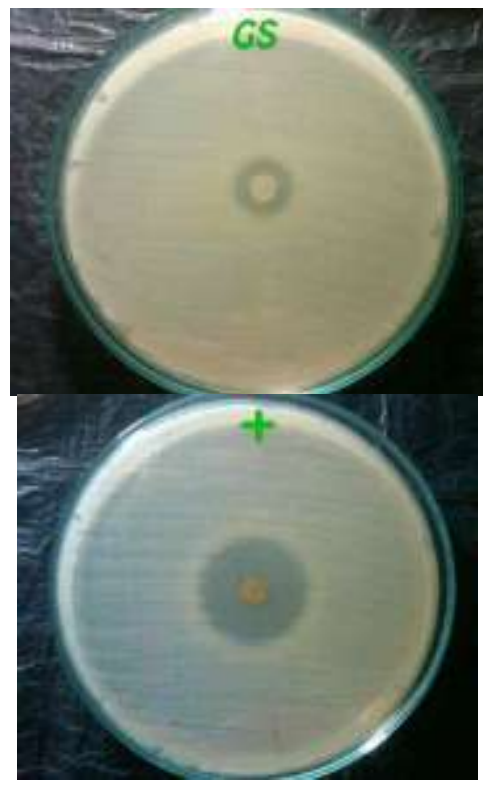

Figure 1: Inhibitory zone of the betel leaf extract gel towards Aa and Pg bacteria

The plate/disk diffusion method was used to determine the sensitivity or resistance of pathogenic bacteria grown on Mueller-Hinton agar (MHA) with various microbes in a paper disk. The absence of microorganisms growth around the disk showed the betel leaf compounds potential on inhibiting bacterial growth.

\section{Discussion}

Based on the qualitative phytochemical analysis, betel leaf extract contained alkaloids, flavonoids, polyphenols, tannins, monoterpenoids, and sesquiterpenoids. Phytochemical tests were performed to see the metabolite content in the experimental sample as a strong foundation that the betel leaf extract has antibacterial potential because phenolic group compounds have high effectiveness as an antibacterial agent. The antibacterial property of the betel leaf extract caused by the phenol compounds that are bactericidal. Phenols binding the bacterial cell walls cause protein denaturation and increase the permeability of bacterial cell walls. The protein molecules balance will change and resulting in changes in the protein structure and cause coagulation. Denaturated and coagulated proteins will lose the physiological activity and unable to function properly. Changes in the protein structures of the bacterial cell wall will increase the permeability of cells, and therefore, the cell growth will be inhibited and damaged[9]

Betel leaf also contains flavonoids that act as an antibacterial by forming complex compounds against extracellular proteins that interfere with the integrity of bacterial cell membranes. Alkaloids also have an antibacterial activity by interfering the peptidoglycan component of the bacterial cell 


\section{International Journal of Science and Research (IJSR) \\ ISSN (Online): 2319-7064}

Index Copernicus Value (2016): 79.57 | Impact Factor (2015): 6.391

that makes the cell wall layers formed uncompletedly and causes cell death. Tannin also has antibacterial activity by shrinking the cell wall or the cell membrane to interferes the cell permeability and makes the cell unable to perform its life activities and therefore inhibits the growth[10],[11].

The results showed that the MIC of betel leaf extract towards the Aa bacteria was as much as $12.5 \%$ and towards the $\mathrm{Pg}$ bacteria was as much as $25 \%$. The Aa bacteria appeared to be more sensitive towards the antibacterial activity of the betel leaf extract. The intensity of an antimicrobial action expressed in the concentration level required on achieving an antibacterial effect. The intensity of activities expressed in MIC means the minimum boundary level of an antimicrobial that works in-vitro against particular bacteria. This condition depends on certain bacterial sensitivity, the amount of inoculum, and the medium used for bacterial culture[9].

The method used to evaluate the antibacterial activity of the betel leaf extract towards the Aa and Pg bacteria was the agar diffusion method, a method most commonly used to determine the susceptibility of bacteria towards the experimental material[11]. The results showed that the inhibitory zone of the betel leaf extract towards the Aa bacteria was $14.70 \mathrm{~mm}$ and towards the Pg bacteria was 8.95 $\mathrm{mm}$. This results meant that the inhibitory potential of the betel leaf extract towards the Aa bacteria has a wider zone, and therefore showed the higher sensitivity of the Aa bacteria towards the antibacterial activity of the betel leaf extract compared to the Pg bacteria. The inhibitory zone diameter strongly influenced by several factors such as the toxicity and diffusion ability of the experimental material, the interaction between the medium components, and the micro-environment conditions in-vitro[11].

The tetracycline antibiotic inhibitory zone towards the Aa and Pg bacteria, however, was still higher than the betel leaf extract. Nevertheless, the antibiotics consumption occasionally causes unwanted side effects causing new problems. ${ }^{11}$ A study conducted by Pratiwi stated that the inhibitory zone of the betel-containing toothpaste towards Streptococcus mutans was as much as $22.03 \mathrm{~mm}$, whilst another study conducted by Limsuwan et al. stated that the inhibitory zone of the betel leaf extracts towards Streptococcus pyogene was as much as $26 \mathrm{~mm}$. The research on the betel leaf antibacterial activity towards gram-positive bacterias, which were Streptococcus mutansand Streptococcus pyogene showed a wider inhibitory zone, probably caused by species difference[12],[13].

Gram-negative bacteria have more complex cell wall structure that is difficult to penetrate. Most gram-negative bacteria have polysaccharide complex on their cell walls. The substance is endotoxin, with the lipopolysaccharide structure is the O-specific polysaccharide which is the antigen that induces a specific immunity. Gram-negative bacteria also have a thinner cell wall peptidoglycan layer that makes the faster recovery process of the peptidoglycan layer when damaged by antimicrobial activity and differs the bacterial cell sensitivity[9],[14].
The Pg and Aa bacteria play an important role in the pathogenesis of periodontal disease, which leads to the tissue damage. A study conducted by Mane et al. showed that the percentage of the $\mathrm{Pg}$ bacteria in periodontitis patients was as much as $46 \%$ and in healthy patients was as much as $12 \%$. This conditions indicated that the presence of $\mathrm{Pg}$ bacteria was associated with periodontal disease. Microorganisms are able to cause tissue damage both directly and indirectly. Directly by invading the tissues and indirectly by producing enzymes and bacterial toxins[3],[15].

PorphyromonasGingivalis ( $\mathrm{Pg})$ formerly known as Bacteriodesgingivalis, is a gram-negative bacteria. The $\mathrm{Pg}$ virulence mechanism was by having an external carbohydrate capsule that prevents opsonization by complements and inhibits phagocytosis by neutrophils. Lipopolysaccharide (LPS) is able to inhibit the leukocytes chemotaxis. These bacteria are also allegedly possessing several other virulent factors such as proteases that degrade immunoglobulins, hyaluronic acid, adhesion, endotoxins, and cytotoxins that can directly affect the periodontium tissue or the function of the body's immune response that causes damage to the gum and bone tissues in periodontal disease. The Pgbacteria stimulates macrophages to secrete proinflammatory cytokines. LPS is a major component that contributes to the inflammatory response. Proteases such as Arg-gingipain, Lys-gingipain, and proteolytic enzymes are able to degrade various proteins in the body and cause inflammation. The Pg bacteria has the ability to invades the gingival fibroblasts and oral epithelial cells[15],[16].

\section{Aggregatibacteractinomycetemcomitans (Aa) formerly} known as Actinobacillusactinomycetemcomitans, is a facultative gram-negative bacteria. The presence of these bacteria in the periodontal pocket often associated with an aggressive periodontal disease. Various virulence factors of the Aa bacteria such as leukotoxin, chemotaxis inhibition, immunosuppressive factors, collagenase lipopolysaccharide, and polymorphonuclear (PMN) leukocytes function inhibition. Leukotoxin is the most important virulence factor that has a destructive effect on neutrophil, monocytes, and T-lymphocytes by leading to the local immunosuppressive in the supragingival areas that having a central role in the development of periodontal lesions in aggressive periodontitis case. LPS is able to stimulate the macrophages to release IL-1, IL-1 $\beta$, and TNF. These cytokines have an important role in tissue and bone damaging[15],[17].

\section{Conclusion}

Thebetel leaf extract gel was having the ability to inhibit the growth of Aggregatibacteractinomycetemcomitans and Porphyromonasgingivalis.

\section{References}

[1] L. Trombelli, D.N Tataks, "Periodontal disease: current and future indication for local antimicrobial therapy," Oral Disease, 9, pp. 11-15, 2013.

[2] A.R Pradeep, P. Bajaj, E. Agarwal, N.S Rao, S.B Naik, N. Kalra, et al., "Local drug delivery of $0,5 \%$ azithromycin in the treatment of chronic periodontitis 


\section{International Journal of Science and Research (IJSR) \\ ISSN (Online): 2319-7064 \\ Index Copernicus Value (2016): 79.57 | Impact Factor (2015): 6.391}

among smokers," Australian Dental Journal, 58, pp.3440, 2013.

[3] A.K Mane, A.P Karmarkar, Bharadwaj, "Anaerobic bakteria in subjet with chronic periodontitis and periodontal health," J Oral Health Com Dent, 3(3), pp.49-51, 2009.

[4] P.M Preshaw, J.J Taylor, "Periodontal pathogens," In Carranza's clinical periodontology, $11^{\text {th }}$ ed. St. Missouri, Elsevier Saunders, 2012.

[5] S. Ciancio, A. Mariotti, "Antiinfective therapy," In Carranza's clinical periodontology, $11^{\text {th }}$ ed. St. Missouri, Elsevier Saunders, 2012.

[6] A. Harrera, L. Franco, L. Fang , A. Diaz Cabellero, "Susceptibility of Porphyromonasgingivalis and Streptococcus mutans to antibacterial effect from Mammea Americana," Advance in Pharmacological science, pp. 1-6, 2014.

[7] S. Murugesan, P. Marimuthu, V. Sakthivel, L. Mani, S. Srinivasan, "Chemical composition and antimicrobial activity of Piper betle Linn leaf oil," Journal of Pharmacy Research, 4(10), pp. 3424-3426, 2011.

[8] N. Kushagra, K.S Mukesh, A. Amit, K. Takeswhar, D. Dhansay, B. Hemant, et al., "Piper betle L: A review on its ethnobotany,phytochemistry, pharmacological profile and profiling by new hyphenated technique DART-MS," Journal of Pharmacy Research, 4(1), pp. 2991-2997, 2011.

[9] S.J Cavalieri, R.J Harbeck, Y.S McCarter, J.H Ortez, I.D Rankin, R.L Sautatter, et al., "Manual of antimicrobial susceptibility testing," American society for microbiology, USA, 2005.

[10] T.P.T Cushnie, A.J Lamb, "Amtinicrobial activity of flavonoids," International journal of antimicrobial agents, 26, pp.343-356, 2005.

[11]A. Sabir, "In vitro antibacterial activity of flavonoid Trigonasppropolis against Streptococcus mutans," Dent. J , 38(3), pp.135-141, 2005.

[12] R.Pratiwi, "The difference of inhibition zones toward Streptococcus mutans among several herbal toothpaste," Dent J, 38(2), 64-67, 2005.

[13] S. Limsuwan, S.P Varavuthikunchai, "AntiStreptococcus pyogenes activity of selected medicinal plant extracts used in Thai traditional medicine," Trop J Pharm Res, 12(4), pp. 535-540, 2013.

[14] V. Bobbarala," Antimicrobial agents," 2012, Croasia, published by InTech, 2012.

[15]L. Kesic, J. Milasin, M. Igic, R. Obradovic, "Microbial etiology of periodontal disease," Medicine and Biology, 15(1),pp.1-6. 2008.

[16] A. Japoni, A.Vasin, S. Noushadi, F. Kiany, S. Japoni, A. Alborzi, "Antibacterial susceptibility patterns of Porphyromasgingivalis isolated from chronic periodontitis patients" Med Oral Patol Oral Cir Bucal, 16(7), pp.1031-1035, 2011.

[17]L. Kesic, M. Petrovic, R. Obradivic, A. Petcic,'The importance of Aggregatibacteractinomycetemcomitans in etiology of periodontal disease," ActaMedicaMedianae, 48(3),pp. 35-37, 2009.

Volume 6 Issue 12, December 2017 www.ijsr.net 